\author{
Anna Gawet* \\ ORCID: 0000-0002-1861-2924 \\ Kraków, Poland
}

\title{
Education for Health as Bodily and Spiritual Well-Being
}

\author{
Edukacja do zdrowia \\ jako cielesnoduchowego dobrostanu
}

\begin{abstract}
Summary: The search for a conception of health education that could be contained within the framework of the pedagogical category of integral education is associated with the contemporary philosophy of health and the basic beliefs of which allowing for the identification of health with biopsychosocial well-being. In the context of the contemporary cultural valuation of the body education faces a number of difficulties and is falling short in many areas. One of the directions proposed within health education is to base its teleological foundations on the integral vision of man, in which he constitutes the ontic whole of the bios and psyche, the organic body and the spiritual life, organized by the principle of the personal "I". The implementation of such goals requires the reference to values, hence in the integral approach to health education, the key task is to shape axiological awareness in relation to the value of the human body.
\end{abstract}

* Dr hab. Anna Gaweł is a professor at the Jagiellonian University, at the Faculty of Philosophy, at the Institute of Pedagogy. Address: Instytut Pedagogiki UJ, ul. Stefana Batorego 12, 31-135 Kraków, Poland; e-mail: anna.gawel@uj.edu.pl. 
Keywords: health; human body; well-being; health education; axiological education.

Streszczenie: Poszukiwanie koncepcji edukacji zdrowotnej, która mieściłaby się w ramach kategorii pedagogicznej, jaką jest edukacja integralna, jest powiązane ze współczesną filozofią zdrowia, której założenia pozwalają na utożsamianie zdrowia z biopsychospołecznym dobrostanem (well-being). W kontekście obserwowanej dziś kulturowej oferty wartościowania ciała ta edukacja napotyka szereg trudności i w wielu obszarach jest mało efektywna. Jedną z propozycji ukierunkowania działań podejmowanych $w$ ramach edukacji zdrowotnej jest oparcie ich teleologicznych podstaw na integralnej wizji człowieka, w której stanowi on ontyczną całość biosu i psyche, organicznego ciała i życia duchowego, organizowanych przez zasadę osobowego ,ja”. Realizacja tak ustanowionych celów wymaga odwoływania się do wartości, stąd w integralnym podejściu do edukacji zdrowotnej niezwykle ważnym dziś zadaniem jest kształtowanie świadomości aksjologicznej w odniesieniu do wartości ludzkiego ciała.

Słowa kluczowe: zdrowie; ciało; dobrostan; edukacja zdrowotna; edukacja aksjologiczna.

Reflection on upbringing and its essence, goals, structure and dynamics needs to be well rooted in anthropological philosophy, given that defining the anthropological assumptions embedded in pedagogical thinking in this area of social reality is of particular importance. Pedagogy is an applied science, which means that the theories developed on its grounds are (or should be) directly transposed into pedagogical practice, expressed in the methods used by educators to support the development of young people when accompanying them on the demanding path to maturity.

From the perspective of the integral approach to education, these considerations are grounded in the theory of man as personal being. One of the assumptions of education interpreted in this way is the recognition that man as a person remains in a field of responsibility for his own existence and the existence of others, while also experiencing the freedom to make choices in response to the challenges that life presents ${ }^{1}$. In this context, the reality of

${ }^{1}$ Katarzyna Olbrycht, „Odpowiedzialność pedagoga” [The Pedagogue’s Responsibility], 
education refers to the full bodily and spiritual structure of human existence. This direction of thinking about education includes the realm of the human body and health. It appears, however, that the search for a conception of health education that could be contained within the framework of the pedagogical category of integral education is entangled in the whole philosophy of health generally promoted today. Its basic beliefs, rooted in the definition of health specified in the preamble to the Constitution of the World Health Organization, on the one hand postulate a holistic approach to health that takes into consideration its physical, mental and social aspects and, on the other, allowing for the identification of health with biopsychosocial well-being. This widely shared conception of health is largely complemented by references to a scientifically confirmed thesis about the major role lifestyle and pro-health behaviours play in health, which has contributed to the formulation of the promotional slogan "Your health is in your hands", which has been publicised since the $1980 \mathrm{~s}^{2}$. Recommendations for health education practice, which are based on the contemporary philosophy of health, are in this case not only associated with stressing the need for people to care for their health and improve all its aspects on the basis of the principle that being in good health produces happiness and an overall sense of well-being, but also with the significance of educational activities that target the fostering of attitudes of responsibility for health.

Yet it turns out that in the face of the rapid socio-cultural changes we experience today, education heading in this direction faces a number of difficulties and is falling short in many areas. From the point of view of integral education, this situation may be rooted in the revaluation of the role of physical dimension of health in well-being observed in the socialization and educational process today, whereas man's existential situation takes place not only in a biological but also a mental, social and spiritual reality. Therefore, the question to ask in this context is how best to design educational activities in a way that can help young people attain full health. In this paper we will consider the philosophy of man as a personal being for answers to this question.

in: Edukacja aksjologiczna, vol. 2, ed. Katarzyna Olbrycht (Katowice: Wydawnictwo Uniwersytetu Śląskiego, 1995), 11-18.

2 World Health Organization, Targets for health for all 2000 (Copenhagen: World Health Organization Regional Office for Europe, 1985). 


\section{The dimensions of health}

The increased social interest in health and change in the perception of it characteristic of the second half of the twentieth century originate in a radical departure from assumptions based on Cartesian dualism. In response to the rejection of the philosophy that separates soma from psyche, the idea of holistic and systemic thinking emerged from the work of Ludwig von Bertalanffy and his general system theory ${ }^{3}$, which advocates the anti-mechanical and anti-reductionist treatment of living organisms as organised dynamic entities whose individual parts and processes are in mutual interaction. According to this approach, a full explanation of the essence of health requires not only looking at its many constituent dimensions but also giving consideration to the mutual relations occurring between them. This means admitting that the level of health that man has at his disposal at any given moment in life is an effect of systemic relations occurring in the sphere of biology and psyche but also in everyday behaviours and the natural, physical and psychosocial life environment. Marc Lalonde's ${ }^{4}$ concept of the determinants of health turned out to be a confirmation of and reference point for this thesis. Lalonde proposes that our health depends not only on the factors that we cannot control, such as our genetic makeup, age, gender, level of medical care and the environment but also on our lifestyle and everyday behaviours. This includes the role of nutrition and physical exercise but also the use of drugs and psychoactive substances, length of rest and sleep, stress-coping strategies etc. A particular characteristic of the contemporary concept of health is understanding it in terms of well-being: according to the classic WHO definition, "Health is a state of complete physical, mental and social well-being and not merely the absence of disease or infirmity". This definition of well-being was later amended with the dimensions of spirituality, sexuality and procreation.

Physical well-being is linked with the functioning of the human body. The natural sciences, primarily biology and medicine, assume that physical

${ }^{3}$ Ludvig von Bertalanffy, General System Theory: Foundations, Development, Applications (New York: George Braziler, 2015).

${ }^{4}$ Marc Lalonde, A New Perspective on the Health of Canadians (Ottawa: Government of Canada, 1974).

5 World Health Organization, "Preamble to the Constitution of the World Health Organisation", Official Records of the World Health Organisation 2 (1946): 100. 
health is a state characterized by the correct structure and functions of all tissues and organs, with internal balance and adaptive abilities ensuring the biological efficiency of the body in response to the changing parameters of the external and internal environment. It should be also noted that although the body is a real being and health is a phenomenon, the two are closely related. The experience of earthly life can only occur through a body whose functioning manifests itself in a certain level of health. The occurrence of health is, then, only possible owing to the body. Furthermore, the human body is not only an actually existing object, and subject to cognition of an external, empirical reality, but it is also experienced internally. The subjective perception of corporeality may have both positive and negative aspects, as it manifests itself not only at the level of the soma (e.g. the ability to take on physical effort, agility, dexterity, muscular strength, feeling of vital strength as well as feeling pain and discomfort) but also within the human psyche (e.g. concentration, memory, degrees of emotional response, etc.).

Social health can be understood two-dimensionally. On the one hand, following Talcott Parsons, it is related to the ability to assume social roles and perform tasks typical for an individual's age, gender and position in the social structure and, on the other, it is associated with the sphere of social relationships. In fact, the concept of social well-being is primarily conveyed through the achievement of a certain level of syntony in relationships with others. A positive measure of the social dimension of health understood in this way is having an appropriate level of social competences, in health education referred to as life skills, which are formed in the course of life experiences as well as through educational and therapeutic interventions. The sense of social well-being is quite clearly related to the notion of mental well-being; hence the term psycho-social health is often used in this context.

The concept of mental health is open to various interpretations, depending on the theoretical framework adopted. Nowadays, the emphasis is particularly on identifying the positive indicators that testify to healthy personality development or the positive adaptation to the changing conditions of life. Often mentioned among the measures of this aspect of health are the efficient functioning of cognitive, emotional and activity structures ${ }^{6}$; also included are other aspects of mental health, such as the ability to realize indi-

${ }^{6}$ Krystyna Ostrowska, „Zdrowie młodzieży w aspekcie psychicznym” [Teenagers' health in its mental aspect], in: Zdrowie dzieci i młodzieży w aspekcie fizycznym, psychicznym, spotecznym i duchowym, eds. Andrzej Jopkiewicz, Jan Schejbal (Kielce: Kieleckie Towarzystwo Naukowe, 1998), 131-142. 
vidual intellectual potential and maintain emotional stability, as expressed by the ability to control emotions (including their recognition and expression in a socially acceptable way while remaining comfortable) and coping with difficulties, stress, tension, depression and anxiety ${ }^{7}$. The indicators specified in this way clearly mark the area of mental well-being, although the approach is not universal. Various psychological approaches also include spiritual elements in this definition, for example Kazimierz Dąbrowski suggests that mental health includes "the ability to develop towards a comprehensive understanding, experience, discovery and creation of an increasingly higher reality and values" ${ }^{8}$. In health psychology, pedagogy of health and health education spiritual elements are included in the spiritual dimension of health in view of the existence of empirically confirmed links between spirituality and indicators of physical health'.

Yet attempts to make the notion of spiritual health or spiritual well-being more precise and accurate have encountered a number of difficulties, if only because in science the meaning of the concept of spirituality itself remains equivocal and underdefined as a consequence of the adoption of certain anthropological assumptions. It has been linked to the various paths of searching for the Absolute, captured in the categories of personal development and self-realization; but it has been also identified with the highest levels of non-somatic development of the human being, such as cognitive, affective and moral, embedded in the stream of the development of the self ${ }^{10}$. On Christian grounds spirituality is primarily considered in its theological aspect and is understood as the form of a spiritual religious life aimed at union with God $^{11}$.

From the point of view of health psychology, spirituality enjoys the status of a theoretical construct and therefore is not directly measurable. It

${ }^{7}$ Barbara Woynarowska, Edukacja zdrowotna. Podręcznik akademicki [Health education: an academic handbook] (Warszawa: Wydawnictwo Naukowe PWN, 2007), 30.

${ }^{8}$ Kazimierz Dąbrowski, „Co to jest zdrowie psychiczne” [What is mental health?], in: Zdrowie psychiczne, ed. Kazimierz Dąbrowski (Warszawa: Państwowe Wydawnictwo Naukowe, 1981), 29. The quote has been translated for the purposes of this paper.

9 Irena Heszen-Niejodek, „Wymiar duchowy człowieka a zdrowie” [Man’s spiritual dimension and health], in: Zasoby osobiste i społeczne sprzyjajace zdrowiu jednostki, eds. Zygfryd Juczyński, Nina Ogińska-Bulik (Łódź: Wydawnictwo Uniwersytetu Łódzkiego, 2003), 33-47.

${ }^{10}$ Ken Wilber, Integral Psychology: Conscioussness, Spirit, Psychology, Therapy (Boston: Shambala Publications Inc, 2000).

${ }^{11}$ Marek Daniluk, „Duchowość chrześcijańska” [Christian spirituality], in: Encyklopedia Katolicka, vol. IV (Lublin: TN KUL, 1983), 317-318. 
is treated as an attribute of the human being, expressed in the capacity for transcendence towards the values of the non-material sphere, which manifests itself in the specific forms of inner religious activity and experience ${ }^{12}$. This approach has been adapted in health education, where it is assumed that spiritual well-being is shaped by those human mental properties that enable us to discover and experience the transcendent dimensions of human existence. In this sense, the field of values, freedom and responsibility is inscribed in the spiritual health of man.

\section{The contemporary cultural valuation of the body and its role in the bodily and spiritual constitution of man}

The physical dimension of health is linked with the material body, which constitutes a being through which man's presence is materialized in the world. The ontological aspect of the human body has a number of other functions, among them the epistemological as a determinant of the existence of cognitive processes, emotional and creative related to human sexuality and sensuality, communicative and social, active and creative, health and therapeutic, recreational and sports-oriented, pragmatic and folk, aesthetic and decorative as well as religious ${ }^{13}$. Analysing the multiplicity of meanings related to these functions, one could propose a thesis suggesting that it is the body that determines the cultural success of the human being. This is what happens in modern society, defined by Bryan Turner as the somatic society ${ }^{14}$. The socio-cultural changes, expressed not only in the increased interest in the body but, even more so, in the spread of the cult of youth and fitness, the development of the industry of aestheticizing and modifying the body and the previously unprecedented expansion of the media coverage of content relating to the body and health have resulted in the re-evaluation of corporality in individual and social life.

${ }^{12}$ Irena Heszen, Helena Sęk, Psychologia zdrowia [Psychology of health] (Warszawa: Wydawnictwo Naukowe PWN, 2007), 72.

13 Stanisław Kowalczyk, Ciało człowieka w refleksji filozoficznej [Human body in philosophical reflection] (Lublin: Katolicki Uniwersytet Lubelski, KUL, 2009).

${ }_{14}$ Bryan S. Turner, Regulating Bodies. Essays in Medical Sociology (London: Routledge, 1992), 12. 
From the educational perspective, the media play a particular role in the formation of young peoples' attitudes of body affirmation. This is linked to the fact that the traditional mass media and the continually improved new generations of the electronic media, which create these attitudes, are now part of our social reality from the youngest age. Among the carriers of values and ideals of the contemporary body cult are the television, film, the Internet and advertising and the popular content broadcast by them, particularly in advertising, use techniques that create extraordinary possibilities for impacting the emotions and imagination while having an important socializing function.

Media messages are full of images of the body and health, representing or symbolizing physical fitness, energy, vitality and beauty, accompanied by openness to social contacts, satisfaction with family and professional life, and motivation to realize one's passions and talents, which is almost everything that falls within the definition of well-being. Notably, the media space is powerfully saturated with information on how to maintain and perfect physical health. Media reports not only convey a lot of information about the rules of nutrition, ways of preventing disease or home remedies, including over-the-counter drugs. They also produce countless instructions on how to become younger-looking, fitter and more sexually attractive. In addition to the many suggestions on how to realize the values of physical health by taking up various sporting disciplines as well as other active forms of leisure and recreation, a lot of space is devoted to the promotion of the therapies, services and products of the dynamically growing "body industry", aimed at its nurturing, modelling and aestheticizing. In fact, it can be safely said that what we are dealing with today is cultural pressure pointing us in the direction of the value of the shape, dimensions and surface of the body while it is also being objectified. We are from the earliest age fed the idea of the body being "transformable", providing we consume certain products, services and treatments and use the recommended patterns of body care while, at the same time, we are presented with suggestive images of the culturally desirable and socially expected body image. As its "owner", man begins to treat the body as an "object-for-me" and takes care of it in a way that places it in the centre of activities aimed at achieving happiness and well-being. It can therefore be concluded that the body valuation inherent in popular culture is close to the Cartesian isolation of the human body from the non-corporeal dimensions of its existence. In this context it is worth recalling the words of Andrzej Pawłucki, who says that "the value of the body exists only in communication with another value, and [...] it is always the value inferior in relation to the 
other. When the body becomes exclusively a value in itself, man denies his own dignity, ceases to be a person"15.

An altogether different concept of the body and the related attitudes towards it is proposed by the philosophy of man as a personal being which argues that man as personal being is an integral whole, constituted by the body and the soul - which organizes matter into a human body and acts through it. The basic manifestation of the soul as the source and the principle of the human person is its mental expression, connected with corporeality by the structures of the nervous system, and a spirituality which is irreducible to matter. The personal dimension of man is therefore manifested through the possibility of intellectual cognition and also through rationally and responsibly experienced freedom. A human person can experience freedom rationally and responsibly in seeking to achieve perfection through the updating of the potentialities of the vegetative, sensory-sensual and spiritual areas of life ${ }^{16}$. The body, thus located within a person, requires care, protection and improvement, as it is an inalienable part of the psychophysical personality of $\operatorname{man}^{17}$. As emphasized by John Paul II, the body enables us to perform specifically human actions and "Through these actions the body expresses a person therefore Man is a subject because of self-awareness and self-determination, but also on the basis of his own body"18.

The integral vision of man is also part of Victor E Frankl's thought. The author of logotherapy theory assumes that man is a unity of three layers, the position of which in the structure of being is concentric in character with the innermost layer being the spiritual, which enables him to become the subject of his own life and take responsibility for it. The assumption that the outer layers are not the cause but the condition for the emergence of the higher layers seems of particular importance. The specific organization of the somatic layer thus allows for the appearance of the mental layer, and its specific form enables the expression of human spirituality. On this approach, the relationship between a person and a somatic organism is instrumental in

${ }_{15}$ Andrzej Pawłucki, Nauki o kulturze fizycznej [On physical culture] (Kraków: Oficyna Wydawnicza „Impuls”, 2015), 18. The quote has been translated for the purposes of this paper.

${ }^{16}$ Mieczysław Albert Krąpiec, „Człowiek bytem osobowym” [Man as personal being], in: Wychowanie na rozdrożu. Personalistyczna filozofia wychowania, ed. Franciszek Adamski (Kraków: Wydawnictwo Uniwersytetu Jagiellońskiego, 1999), 85.

${ }^{17}$ Kowalczyk, Ciało człowieka, 138 i nast.

18 John Paul II, Man and Woman He Created Them. A Theology of the Body (Slough: Pauline Books and Media, 2011), 154. 
nature, because the psychophysical organism that belongs to man is a tool for the spirit ${ }^{19}$.

The role of the bodily dimension of health, interpreted in this way, definitely broadens the culturally modelled argument for taking care of the nurturing and appearance of the body while exploring its potential abilities.

\section{Final thoughts. The integral approach to health education}

The salutogenic thesis, which proposes that health can not only be protected but also perfected, is one of the pillars of modern health education. According to Aaron Antonovsky, the author of the concept of salutogene$\operatorname{sis}^{20}$, health is a process and its progress towards increasingly better indicators makes it possible to achieve fuller well-being. At the same time, it is often emphasized that the process of acquiring health is a function of the resources and deficits inherent in a person and also in environmental conditions $^{21}$. From the point of view of health education, a special role is played by the resources intrinsic to human health awareness, which translate to health-related activity. Considering that today's health awareness is largely shaped by the cultural message, particularly that proliferated by the media, an important task for health education is the development of a well thoughtout intervention in the process of the socialization of health, both at the stage of primary socialization and in its further course.

In the context of the current cultural tendency to separate the body from the rest of human experience, one of the directions proposed within health education is to base its teleological foundations on the integral vision of man, in which he constitutes the ontic whole of the bios and psyche, the organic body and the spiritual life, organized by the principle of the personal "I". The implementation of such goals requires the reference to values, hence axiological education is an indispensable component of health education.

The analysis of the axiological status of the body and the health phenomenon founded on it, which provide not only energy and life force but also the material bases for mental processes, leads us to the recognition that

19 Victor Emil Frankl, Homo patiens (Warszawa: Instytut Wydawniczy PAX, 1984), 219.

${ }^{20}$ Aaron Antonovsky, Unravelling the Mistery of Health. How People Manage Stress and Stay Well (San Francisco: Jossey-Bass Publishers, 1987).

${ }^{21}$ Heszen, Sęk, Psychologia zdrowia, 63-64. 
without them it is not possible for other values to exist in man's axiological space. Justifying the concern for body and health by the need to feel well and enjoy social approval is therefore, undeniably, not enough. The body and health serve the good of man in all dimensions of life; moreover, they not only serve their actual "owner" but also the others to whom a person is related in all kinds of ways. It can therefore be said that in a sense they meet the criteria of autotelic value, which demands the realization of the fulfilment of man as a human person.

Today, in the integral approach to health education, the key task is to shape axiological awareness in relation to the value of the human body. Piotr Błajet $^{22}$, referring to the anthropology of John Paul II, which points to the primary senses of the body - "primeval loneliness", "original unity" and "primordial nudity" 23 - proposes that educational activities be based on "the triad of the pedagogy of the body". Consequently, he stresses the need to develop students' ability to internalize their bodily activity, to foster sensitivity to other people and create a sense of community and unity with others. Referring to the sense of "primordial nudity", he also discusses the pedagogy of sexuality, in which the body is not reduced to being a passive object of desire but is a subject capable of bestowing erotic love on another, whose acts are an expression of the unity of the body and the Spirit and, in this way, a denial of the opposition of sensuality and spirituality.

A valuable argument for the inclusion of health in the area of axiological education may be found in the philosophical thought of John Paul II, who drew a distinction between the absolute values manifested in the person, and subjective, relative values such the aesthetic, intellectual and vital. According to John Paul II, any subjective value can become absolute if found in the "field of morality", when its realization perceived through the obligation considered in free human conscience is related to its personal development ${ }^{24}$. Following this direction, one can assume that in education, demonstrating axiological relations between moral and subjective values serves the purpose of moulding students' moral sensitivity. Health, with its axiological carriers,

22 Piotr Błajet, Ciało jako kategoria pedagogiczna. W poszukiwaniu integralnego modelu edukacji [Body as a pedagogical category. In search of the integral model of education] (Torun: Wydawnictwo Uniwersytetu Mikołaja Kopernika, 2006), $150 \mathrm{n}$.

23 John Paul II, Man and Woman.

${ }^{24}$ Katarzyna Olbrycht, Prawda, dobro i piękno w wychowaniu człowieka jako osoby [Truth, goodness and beauty in the education of man as a person] (Katowice: Wydawnictwo Uniwersytetu Śląskiego, 2000), 178. 
i.e. health behaviours, which are often linked to the need to make decisions and consider choices, remains well within this line of reasoning. Accordingly, health becomes the subject of moral choices made by man in terms of the duty to one's own person and responsibility for dealing with one's own body and health. In this way, health takes on the character of an absolute value.

The realization of values in life is possible when they are felt and accepted, which first requires that they are recognized. Influencing young people's ability to recognize the value of the body and health as well as shaping attitudes of responsibility for actions taken towards them is, in connection with the educational support given to the body's physical and psychosocial development, the most basic goal of health education. In the integral approach to health education, one cannot ignore the spiritual sphere of young people's health, with the transcendent reality being its reference point. This reference allows us to construct education for the value of the body and health as bodily and spiritual well-being on strong and reliable foundations.

\section{References}

Antonovsky, Aaron. Unravelling the Mistery of Health. How People Manage Stress and Stay Well. San Francisco: Jossey-Bass Publishers, 1987.

Bertalanffy, Ludvig. General System Theory: Foundations, Development, Applications. New York: George Braziler, 2015.

Błajet, Piotr. Ciało jako kategoria pedagogiczna. W poszukiwaniu integralnego modelu edukacji [Body as a pedagogical category. In search of the integral model of education]. Toruń: Wydawnictwo Uniwersytetu Mikołaja Kopernika, 2006.

Daniluk, Marek. „Duchowość chrześcijańska” [Christian spirituality]. In: Encyklopedia Katolicka, vol. IV, 317-318. Lublin, TN KUL, 1983.

Dąbrowski, Kazimierz. „Co to jest zdrowie psychiczne” [What is mental health?]. In: Zdrowie psychiczne, ed. Kazimierz Dąbrowski, 7-35. Warszawa: Państwowe Wydawnictwo Naukowe, 1981.

Frankl, Victor Emil. Homo patiens. Warszawa: Instytut Wydawniczy PAX, 1984.

Heszen, Irena, Helena Sęk. Psychologia zdrowia [Psychology of health]. Warszawa: Wydawnictwo Naukowe PWN, 2007.

Heszen-Niejodek, Irena. „Wymiar duchowy człowieka a zdrowie” [Man’s spiritual dimension and health]. In: Zasoby osobiste i spoleczne sprzyjajace zdrowiu jednostki, eds. Zygfryd Juczyński, Nina Ogińska-Bulik, 33-47. Łódź: Wydawnictwo Uniwersytetu Łódzkiego, 2003. 
John Paul II. Man and Woman He Created Them. A Theology of the Body. Slough: Pauline Books and Media, 2011.

Kowalczyk, Stanisław. Ciało człowieka w refleksji filozoficznej [Human body in philosophical reflection]. Lublin: Katolicki Uniwersytet Lubelski, 2009.

Krąpiec, Mieczysław Albert. „Człowiek bytem osobowym” [Man as personal being]. In: Wychowanie na rozdrożu. Personalistyczna filozofia wychowania, ed. Franciszek Adamski, 81-92. Kraków: Wydawnictwo Uniwersytetu Jagiellońskiego, 1999.

Lalonde, Marco. A New Perspective on the Health of Canadians. Ottawa: Government of Canada, 1974.

Olbrycht, Katarzyna. „Odpowiedzialność pedagoga” [The Pedagogue’s Responsibility]. In: Edukacja aksjologiczna, vol. 2, ed. Katarzyna Olbrycht, 11-18. Katowice: Wydawnictwo Uniwersytetu Śląskiego, 1995.

Olbrycht, Katarzyna. Prawda, dobro i piękno w wychowaniu człowieka jako osoby [Truth, goodness and beauty in the education of man as a person]. Katowice: Wydawnictwo Uniwersytetu Śląskiego, 2000.

Ostrowska, Krystyna. „Zdrowie młodzieży w aspekcie psychicznym” [Teenagers” health in its mental aspect]. In: Zdrowie dzieci i młodzieży w aspekcie fizycznym, psychicznym, społecznym i duchowym, eds. Andrzej Jopkiewicz, Jan Schejbal, 131-142. Kielce: Kieleckie Towarzystwo Naukowe, 1998.

Pawłucki, Andrzej. Nauki o kulturze fizycznej [On physical culture]. Kraków: Oficyna Wydawnicza „Impuls”, 2015.

Turner, Bryan S. Regulating Bodies. Essays in Medical Sociology. London: Routledge, 1992.

World Health Organization. "Preamble to the Constitution of the World Health Organisation". Official Records of the World Health Organisation 2 (1946): 100.

World Health Organization. Targets for health for all 2000. Copenhagen: World Health Organization Regional Office for Europe, 1985.

Wilber, Ken. Integral Psychology: Conscioussness, Spirit, Psychology, Therapy. Boston: Shambala Publications Inc, 2000.

Woynarowska, Barbara. Edukacja zdrowotna. Podręcznik akademicki [Health education: an academic handbook]. Warszawa: Wydawnictwo Naukowe PWN, 2007. 
